\title{
Geastrum pleosporus sp. nov., a new species of Geastraceae iden- tified by morphological and molecular phylogenetic data
}

\author{
Clovis Douanla-Meli1, ${ }^{*}$, Ewald LANGER 1 \& Francisco D. CALONGE2
}

\begin{abstract}
An unusual species of Geastrum was found growing on decayed wood debris and leaves of Triplochiton scleroxylon in the Mbalmayo Forest Reserve, Cameroon. The species morphologically resembles G. saccatum and G. fimbriatum in having sessile endosperidium partly enclosed by the saccate base of the exoperidium. Microscopically, it is characterized by and distinguished from all other known species of the genus, in having subsmooth, punctate to moderately verruculose, slightly thick- to distinctly thick-walled polymorphous, constricted to eight-shaped, mostly oblong, ovoid, cylindrical, elliptic to clubshaped basidiospores. G. pleosporus was studied from a collection of about fifteen basidiomata covering different stages of development. It is described as new based on morphological analyses and phylogenetic inferences made from large ribosomal DNA sequence alignments. Phylogenetic relationship of G. pleosporus is investigated. In parsimony analyses of partial sequences of the large subunit rDNA from selected Gasteromycetes species, G. pleosporus is closely related to $G$. saccatum within the strongly supported clade of Geastrum species. The cluster of G. pleosporus and G. saccatum is well supported in parsimony analysis of the dataset with Geastrum species and related taxa using parsimony and maximum likelihood analysis.
\end{abstract}

Taxonomical novelty: Geastrum pleosporus Douanla-Meli

Keywords: Earthstar, fibrilose-gleba, LSU rDNA, Lycoperdales, mycosclereids, peridium, polymorphous spores, subiculum

$\mathrm{T}$ he genus Geastrum was erected by PERSOON (1801) with $G$. coronatum Persoon as the type species. It is the most widely distributed and complex genus in the Puffballs and fungi with enclosed hymenophore. Species in this genus are obviously recognised by the distinctly star-like basidiomata at maturity. The young fruitbody buried under leaf litter resembles a small, pointed, globular or dome-shaped puffball, lacking typical narrow stem and cap of other common fungi; the peridium is composed of not less than four layers. As maturity approaches, the exoperidium splits from the apex downwards into several stellate lobes and exposes the endoperidium, which dehisces by a unique stoma. Within the family Geastraceae comprising two other genera, Myriostoma Desv. is distinguished from other earth stars by the multiple perforations on the spore sac and Radiigera Zeller is also similar to an earthstar except that it does not open. CunNINGHAM (1979) estimated about 110 species of Geastrum, currently described are not more than 30 valid species in the genus. Up to 279 species have been described, basically using clas-

\footnotetext{
1 Universität Kassel, Fachbereich 18 Naturwissenschaften, Institut für Biologie, Fachgebiet Ökologie, Heinrich-Plett-Staße. 40, 34132 Kassel, Germany.

2 Real Jardín Botánico, CSIC, Plaza de Murillo 2. E-28014 Madrid, Spain. E-mail <calonge@ma-rjb.csic.es>

* Corresponding author e-mail <cmeli@yahoo.com>, Tel.: (0049) 561 8044215, Fax: (0049) 5618044115
}

sical taxonomy. Morphologically identifying characteristics of Geastrum are the rays that curl back in a star-like manner, this clears a space around the endoperidium which remains seated in the cup thus formed, as it is the case in G. sessile (Sowerby) Pouzar and G. saccatum Fr., or the rays fold tightly over the spore sac and raise the latter like that in G. coronatum Pers., and typically in G. fornicatum (Huds.) Hook., with a peridium carried upon a pseudostem. In other species like G. schweinitzii (Berk. \& M. A. Curtis) Zeller, the fruitbodies sit on a subiculum, a felt like mass of hyphae, which covers rotting wood. In some species the rays expand, but then close up over the endoperidium when they dry out. They are described as hygroscopic and resemble hygroscopic species like Astraeus hygrometricus (Pers.) Morgan. Significantly, however, several species of Geastrum having hygroscopic rays can be distinguished by the presence of a peristome, a columella, and generally smaller spores. Microscopically the striking features of the genus concern the spores. They are globose, or less frequently subglobose, some shade of brown, and almost invariably verrucose or echinulate, produced on 4-8 spored basidia.

Geastrum is the most common Gasteromycete genus in Cameroon (CAlONGe \& Daniëls 1998, HJortstam et al., 1993). In the framework of a research program aimed at the assessment of fungal biodiversity in South Cameroon, periodical collections were carried out. During 2002 we collected several specimens in the Mbalmayo Forest Reserve, belong- 
ing to the genus Geastrum, and the study revealed well-known species such as G. saccatum and G. fimbriatum, representing the first records for Cameroon, while other did not match with any of the described species (PonCE DE LEÓN 1968; CALONGe 1998; CAlonge \& Demoulin 1975; Sunhede 1989; Soto $\&$ WRIGHT 2000, etc.). Besides the typical morphology reminiscent of Geastrum species, the spore patterns observed in the whole collection were unknown in the genus. In this case an exclusively morphological study appears not sufficiently reliable. Therefore molecular tools for their identification were combined. Very limited molecular data are available to infer phylogenetic relationships in Geastrum. In order to test the hypothesis that the fungus is related to Geastrum species, we sequenced a portion of the large subunit rDNA, and included it in two datasets of (a) Gasteromycete species and (b) Geastrum species together with related taxa. Its phylogenetic placement was investigated. Morphological and molecular studies suggested that this is a new species in $G e-$ astrum.

\section{Material and methods}

Basidiomata were collected and dried with a DÖRREX SIGG 6252.10 (Switzerland). The description was made based on the examination of the collection containing fifteen fruitbodies in all stages of development. Colour terms in parentheses are those of KORNERUP \& WANSCHER (1978). Herbaria are cited according to HolmGREN, HoLMGREN \& BARNETT (1990). Holotype specimens are deposited at the herbarium of Cryptogamy Laboratory, Faculty of Science, University of Yaoundé I, Cameroon (HUYI), an isotype at MA-Fungi.

\section{Line drawings, light and scanning electron micro- scopy}

Morphological description was based on fresh material. Microscopic structures were mainly observed on dried material. Free-hand thin sections were mounted in $\mathrm{KOH} \mathrm{(5 \% )} \mathrm{for} \mathrm{more}$ detailed observations. Light microscopy studies were carried out at 400 and $1000 \mathrm{X}$ using an Olympus BX51TF microscope. Line drawings were made using a grid as drawing aid representing a magnification of 52000 . Size ranges of basidiospores were based on at least 50 basidiospores; light photography was done with a Nikon COOLPIX 4500 Digital, and processed in Photoshop (Adobe Photoshop 4.0). For the SEM photographs, just prior to examination with a Hitachi S 4000 Scanning Electron Microscope, dried spores were mounted on platinum stubs and gold coated to a thickness of $20 \mathrm{~nm}$ with a Balzers SCD 020 Coating Unit (Balzers, Liechtenstein).

\section{Nucleic acid extraction, PCR amplification and se- quencing}

Genomic DNA was isolated from dried herbarium specimens using a modified version of SDS method of EDWARDS, JOHN-
STONE \& THOMPSON (1991) and HENRION, LE TACON \& MARTIN (1992). Material for DNA isolation (30-40 mg) was taken from the gleba tissue (mass of spore with capillitium) and the exoperidium. Serial dilutions (1:100, 1:1000) were used as template for the polymerase chain reaction (PCR). Reaction for PCR amplification were performed in $50 \mu \mathrm{l}$ mixture containing $50 \mathrm{mM} \mathrm{KCl}, 20 \mathrm{mM}$ Tris- $\mathrm{HCl}$ (pH 8.4), $75 \mathrm{mM}$ $\mathrm{MgCl}_{2}, 10 \mathrm{mM}$ of each of the four deoxynucleotide triphosphates, $25 \mathrm{pM}$ of each primer, and 1 unit of Taq polymerase. The 5' end domain of the nuclear DNA coding for the large ribosomal subunit (LSU rDNA) was amplified using the polymerase chain reaction (MULLIS \& FALOONA 1987; WHITE et al. 1990) with NL1 and NL4 as primers (O’ DonNELL 1993). The PCR reactions were performed with the TGradient Thermocycler 96, Biometra of Whatman Company. The cycle parameters were an initial denaturation at $94{ }^{\circ} \mathrm{C}$ for $3 \mathrm{~min}$, followed by 35 cycles consisting of denaturation at $94^{\circ} \mathrm{C}$ for $30 \mathrm{~s}$, annealing at $55^{\circ} \mathrm{C}$ for $45 \mathrm{~s}$ and extension at $72{ }^{\circ} \mathrm{C}$ for $60 \mathrm{~s}$, and a final elongation step of $7 \mathrm{~min}$ at $72{ }^{\circ} \mathrm{C}$ was included. PCR products were checked on $0.7 \%$ agarose gel, and purified with the QIAquickTM kit (QIAGEN) according to the manufacturer's instructions. The DNA products were sequenced in both directions with the respective primers NL1 and NL4, using the ABI PRISMTM Bigdye Terminator Cycle Sequencing Kit, Version 3.1, Applied Biosystems, and analysed using an automated DNA sequencer ABI 3100, Perkin Elmer.

\section{Sequence alignment and phylogenetic analysis}

The contiguous nucleotide sequences were edited and assembled using the programs EditSeq and MegAlign of Lasergene (DNASTAR 2000) software for Macintosh, and manually corrected with Se-Al version 2.0a11 (RAMBAUT 2002). Gaps (insertions/deletions) in the alignment were treated as missing data. All positions were included in the final alignment. The three sequences of Geastrum we determined have been deposited in Genbank with the accession numbers AY566241 and AY566242 for G. pleosporus and AY714318 for G. fimbriatum. Additional sequences used for comparative analyses were obtained from GenBank (Tab. 1). We assembled two data sets of LSU sequences by selecting species of Gasteromycetes, and a selection of Geastrum species together with related species. The aligned sequences are deposited in TreeBase in NEXUS format, with accession numbers SN1798.

Phylogenetic analysis was performed with PAUP* (Phylogenetic Analysis Using Parsimony) version 4b10 (SWOFFORD 2002) for Macintosh. Nucleotide substitutions were treated as unordered, equally weighted characters. Gapped positions were included to improve alignment and treated as missing data or were excluded in separate analysis. Maximum parsimony trees were inferred using heuristic search option, Starting tree(s) obtained via stepwise addition, tree-bisection-reconnection (TBR) branch-swapping algorithm was used, MAXTREES reset to 10000 . MULTRESS option (saving of all optimal trees) effective, Steepest descent option in effect, 
Tab. 1: List of taxa included in the phylogenetic analysis, GenBank numbers, strain, sequence data and sequence length. Annotated with $(*)$ the sequences generated in this study.

\begin{tabular}{|c|c|c|c|c|}
\hline Species & Accession no. & Strain & Sequence data & SeqLength \\
\hline Anthurus archeri & AJ406479 & GEL5392 & LSU & 921 \\
\hline Astraeus hygrometricus & AF336238 & Ashy3 & LSU & 906 \\
\hline Auricularia delicata & AF291290 & USJ 54470 & LSU & 585 \\
\hline Auricularia mesenterica & AF291292 & FO 25132 & LSU & 566 \\
\hline Bovista paludosa & AJ237630 & BPRU & LSU, SSU, ITS1\&2 & 695 \\
\hline Bovista plumbea & AJ237629 & DA-54 & LSU, SSU, ITS1\&2 & 694 \\
\hline Calvatia rubro-flava & AF485064 & TENN59078 & LSU & 673 \\
\hline Clathrus ruber & AF213127 & T-9354 & LSU & 615 \\
\hline Clavariadelphus pistillaris & AF213133 & OSC-69446 & LSU & 608 \\
\hline Cyathus stercoreus & AF261583 & T815 & LSU & 938 \\
\hline Cyathus striatus & AF336247 & & LSU & 895 \\
\hline Gautieria gautierioides & AF213123 & OSC-48547 & LSU & 608 \\
\hline Gautieria parksiana & AF213126 & OSC-49803 & LSU & 606 \\
\hline Geastrum fimbriatum & AY714318* & DMC 290 & LSU & 633 \\
\hline Geastrum nanum & AF336250 & & LSU & 908 \\
\hline Geastrum pleosporus & AY566241* & DMC 224a & LSU & 617 \\
\hline Geastrum pleosporus & AY266242* & DMC 224b & LSU & 628 \\
\hline Geastrum rufescens & AF336251 & & LSU & 911 \\
\hline Geastrum saccatum & AF287859 & & LSU & 964 \\
\hline Geastrum sessile & GSE406480 & GEL5319 & LSU & 922 \\
\hline Gomphus floccosus & AF287862 & & LSU & 969 \\
\hline Hysterangium clathroides & AF213121 & SZEMORE & LSU & 618 \\
\hline Hysterangium coriaceum & AF213122 & OSC-69448 & LSU & 612 \\
\hline Lycoperdon echinatum & AJ237622 & LEVB & LSU, SSU, ITS1\&2 & 690 \\
\hline Lycoperdon foetidum & AJ237623 & DA-100 & LSU, SSU, ITS1\&2 & 691 \\
\hline Lycoperdon perlatum & AY264919 & & LSU, SSU, ITS1\&2 & 698 \\
\hline Phallus impudicus & AY152404 & FO 46622 & LSU & 605 \\
\hline Pseudocolus fusiformis & AF213128 & ASM-4705 & LSU & 616 \\
\hline Scleroderma bovista & AF336264 & W\#1149 & LSU & 903 \\
\hline Ramaria rainierensis & AF213115 & M-231 & LSU & 612 \\
\hline Rhizopogon pannosus & AY177254 & Rpa1 & LSU & 878 \\
\hline Rhizopogon pumilionus & AY177252 & Rp1 & LSU & 894 \\
\hline Rhizopogon subareolatus & AY177250 & Rsa1 & LSU & 882 \\
\hline Tulastoma brumale & AF336272 & & LSU & 890 \\
\hline Tulostoma simulans & AF261486 & & LSU & 1131 \\
\hline
\end{tabular}

and zero length branches collapsed. A neighbour-joining (NJ) tree was constructed using the Kimura 2-parameter model (KIMURA 1980). Relative robustness of internal branches was assessed by 1000 bootstrap replications (FELSENSTEIN 1985; HILls \& Bull 1993). Other indices for the generated topology, included tree length, consistency index (CI), and retention index (RI). As outgroup for the two data sets Auricularia delicata (Fr.) Henn. and Auricularia mesenterica (Dicks.) Pers. were chosen based on the results of many phylogenetic studies involving species of Gasteromycetes and related taxa
(HiBBEtT et al. 1997; HuMPERT et al. 2001). In addition, for the two datasets, parsimony analysis was also performed by maximum likelihood (ML) analysis using starting trees for TBR branch swapping with one random taxon addition sequence. Empirical nucleotide frequencies were used: $\mathrm{A}=0.25646, \mathrm{C}$ $=0.21262, \mathrm{G}=0.29862$ and $\mathrm{T}=0.23229$. The transition $/$ transversion ratio was set to 2.0, and the Hasegawa-Kishino-Yano (HKY85) distance model was selected, the ML bootstrap values were generated using a stepwise sequence addition with 100 replicates. 


\section{Results}

\section{Sequence alignment and phylogenetic analysis of the LSU rDNA datasets}

BLAST and FASTA searches using the two LSU rDNA sequences of G. pleosporus (DMC 224a 617 bp and DMC 224b $628 \mathrm{bp}$ fragments) recovered nrDNA sequences of species of Geastrum, Sphaerobolus, Gomphus. Highest scoring matches were with species of Geastrum. The sequences of partial LSU DNA ranged from 608 to $1131 \mathrm{bp}$. All positions were unambiguously alignable among the LSU rDNA of Gasteromycetes, only representative taxa from each group were included in the analysis along with available sequences of Geastrum. The LSU ribosomal DNA data set of 32 taxa was subjected to parsimony analyses. The length of aligned sequences including inserted gaps was 911 characters. Parsimony analysis of the LSU sequences in which indels were treated in various ways, generated MPT (most parsimonious trees) that differed in length, number of trees retained, consistency index and retention index. The MPT generated using different indel treatments were similar in topology, with minor variation at the tips of trees. Analysis with indels excluded and gaps treated as newstate produced eight MPT of shorter length (363 steps) with the same topology and the placement of G. pleosporus. In the parsimony analysis with indels coded with multistate characters and gaps treated as missing, 509 characters were variable, 428 of which were parsimony informative. Parsimony analyses using heuristic search resulted in three equally MPT of 1109 steps with the following scores consistency, retention, and rescaled consistency indices of $0.622,0.836$ and 0.520 respectively. The maximum likelihood analysis of the same sequence alignment yielded a tree with a very similar topology (not shown). The main difference was the lower bootstrap values obtained at different internodes. Phylogenetic analysis identified two major lineages of rDNA as measured by bootstrapping (Fig. 1). The larger lineage was weakly supported at bootstrap value $70 \%$, showing the monophyly of the rest of Gasteromycetes representatives without Geastrum species, further topology resolved two main groups with bootstrap support $64 \%$ and $76 \%$. The former characterised the branch leading to the Phallales and Lycoperdales species and the latter supported the monophyly comprising representatives of Hymenogastrales, Sclerodermatales, Tulostomatales and Nidulariales. The clade of Phallales was confirmed with weak bootstrap support $63 \%$ and the two species of Gautieriales nested within this clade, whereas the clade of Lycoperdales was supported at $100 \%$ bootstrap value. The resolved position of Lycoperdales revealed by the analyses corroborates their phylogenetical separation from Geastrales demonstrated by KREISEL (1969) and reaffirmed by KRÜGER (2001). This study focussed on the placement of G. pleosporus has asserted its generic assignment. All species of Geastrum included in the analysis nested within a unique clade sister to the rest of Gasteromycetes representatives, and strongly supported with $99 \%$ bootstrap value, but failed to be resolved in monphyly. G. sessile was basal in the clade, and the remainder species were moderately supported with $75 \%$ bootstrap value. Further resolutions for each sub-clade alone were high, $89 \%$ and $91 \%$ bootstrap value respectively. G. fimbriatum was sister group to the sub-clade comprising $G$. rufescens and $G$. nanum. G. pleosporus clustered together with G. saccatum in a sub-clade with $89 \%$ bootstrap support. In a neighbour-joining analysis (not shown) that yielded similar topology, G. pleosporus and G. saccatum occupied the same relative position as shown in Fig. 1.

The second alignment consisted only of sequences of $\mathrm{Ge}$ astrum and closely related species, using the sequence of Auricularia mesenterica as outgroup. The available sequence of G. triplex could not be unambiguously aligned with the rest, and was excluded from the phylogenetic analysis. This alignment of 11 taxa included 634 characters; there were 148 variable characters of which 92 were parsimony-informative. Parsimony analysis resulted in a single MPT of 230 steps in length and consistency, retention, and rescaled consistency indices of $0.752,0.731$ and 0.550 respectively. The best fitting ML model selected by Modeltest is the Hasegawa-KishinoYano model with gamma distributed site-to-site rate variation. In analysis with one of the most parsimonious trees as starting tree for branch swapping, the optimal MLT was found with a $\log$ likelihood score of -2106.07633 . The ML analysis recovered the grouping found by the MP analysis with some minor changes in bootstrap values. In the MPT (Fig. 2) and MLT (Fig. 3), Geastrum spp. and related taxa form monophyletic clades with bootstrap values of $100 \%$ and $99 \%$ (100\%) respectively, although the sister relationship was not supported by bootstrap analysis. The topology within the clade of $G e-$ astrum species did not differ from the first analysis, despite minor fluctuations of bootstrap values.

\section{Taxonomy}

Geastrum pleosporus Douanla-Meli sp. nov. Figs. 4-7

Carposoma iuvene epigaeum, adhuc clausum globulare vel depressoglobulare, $1.2-1.5 \mathrm{~cm}$ latum, aurantio-ruber vel fusco-ruber. Endoperidium globulare, sessile, $0.5-0.8 \mathrm{~cm}$ lato, avellaneus vel spadiceus, tenuis. Exoperidium apertum, non hygroscopicum, in 5-6 radios orbicularis, recurvos fissum, stratum myceliale fusco-ruber, persistens, stratum medium aurantio-ruber, tenuis; stratum internum carneum, ad $2 \mathrm{~mm}$ crassus, persistens, peristomio determinato, fibrilloso. Gleba brunnea, columella parva manifesta. Basidiospora laevis in microscopio optico, vel leviter punctulatus in microscopio electronico, polymorpha; globularis, cylindricus, ellipticus, reniformis, clavulatus, leviter crassus vel parva manifesta crassus tunicatus, (3.5) 4-6 (8) $\times$ (3) 4-5 (6) $\mu \mathrm{m}$.

Ad Mbalmayo silva nova, Ekombitie-Cameroon, m 500-650 a.s.1., on emortuus lignum Triplochiton scleroxylon, leg. C. Douanla-Meli, 16.X.2002. Holotypus: herb. HUYI DMC 224. Isotypus: MA-Fungi 56971.

Etymology: Latinised form of polymorphic, referring to the polymorphous spores. 


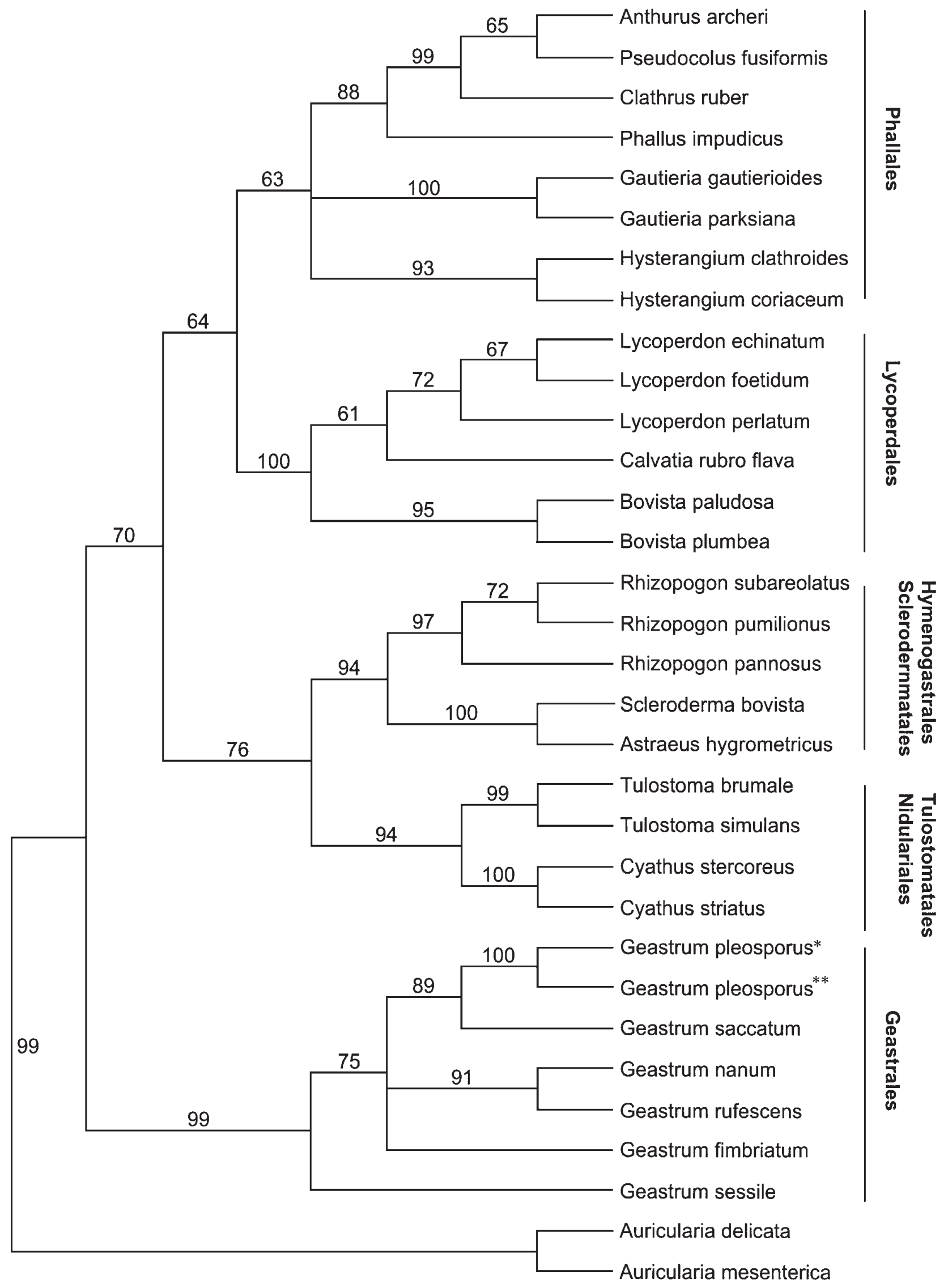

Fig. 1: One of the three equally parsimonious trees generated from heuristic search in PAUP $4 b 10$ based on LSU rDNA sequences from 30 taxa of Gasteromycetes $(\mathrm{L}=1109$ steps, $\mathrm{CI}=0.622, \mathrm{RI}=0.836$ and $\mathrm{RC}=0.520)$. Bootstrap values from 1000 replicates greater than $50 \%$ are shown at the respective internodes. Auricularia delicata and Auricularia mesenterica were used as outgroup. $*=$ DMC $224 \mathrm{a} ; * *=$ DMC $224 \mathrm{~b}$. 


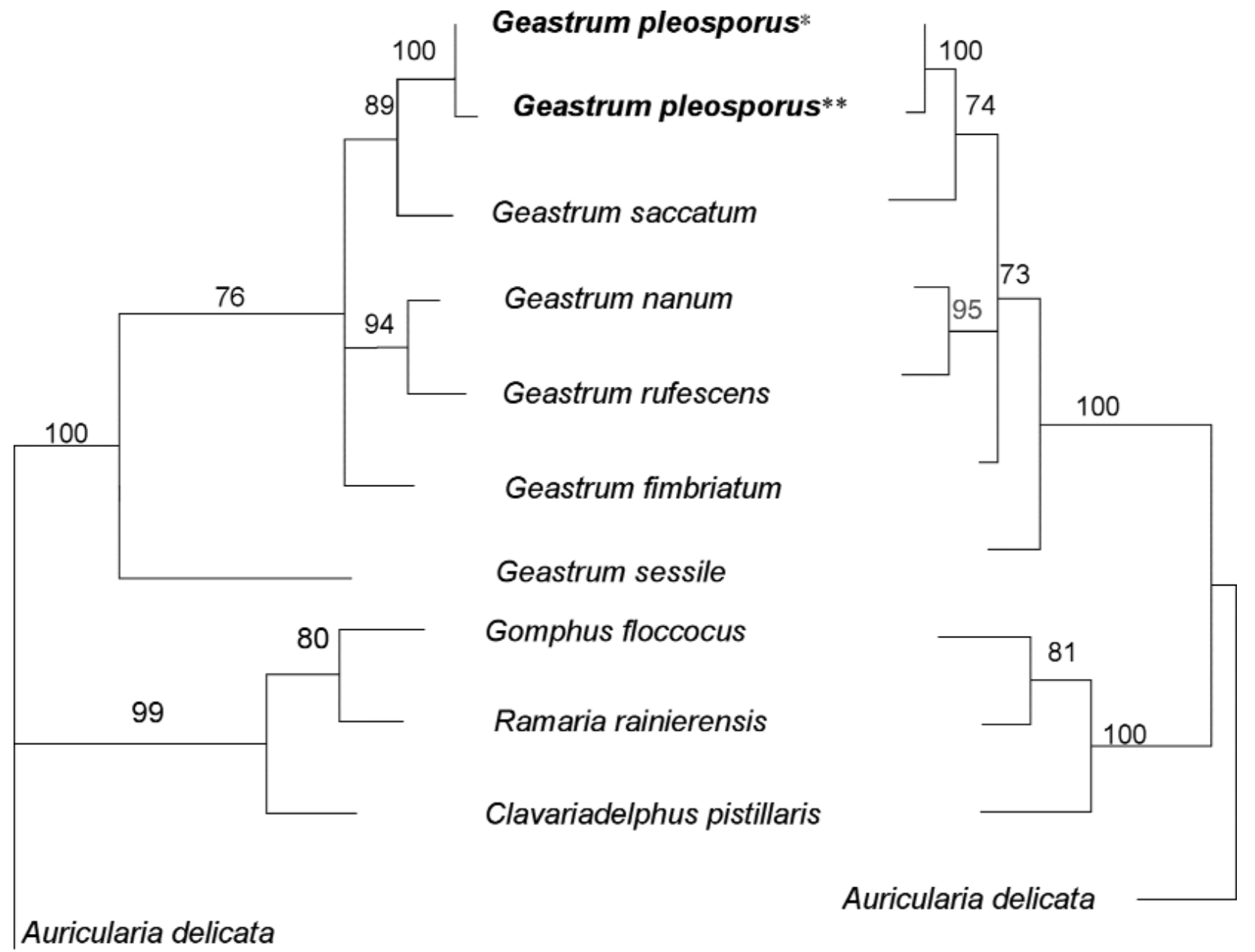

\section{- 10 changes}

Fig. 2: Phylogenetic placement of G. pleosporus. Strict concensus phylogram of the single MPT recovered from maximum parsimonious (MP) analysis of LSU rDNA sequences of Geastrum spp. and related taxa (Lenght $=230$ steps, $\mathrm{CI}=0.752, \mathrm{RI}=0.731, \mathrm{RC}=0.550)$. Bootstrap greater than $50 \%$ are indicated at the respective nodes. Length is given under each branch. Auricularia delicata was used as outgroup.

Unexpanded fruitbody epigeous, globose to depressed globose, up to $1.2-1.5 \mathrm{~cm}$ broad, orange red (8A8) to brown red (8C8), outer surface wrinkled, emerging from a white subiculose mycelium, which grows on plant debris. Expanded fruitbody (Fig. 4) up to $2 \mathrm{~cm}$ broad. Exoperidium non hygroscopic, splitting into 5-6 star-like, thick, round-tipped rays, up to $5 \mathrm{~mm}$ long that eventually roll downwards. Endoperidium globose, initially dusted, covered by a powdery or meal layer, soon glabrous, sessile, $0.5-0.8 \mathrm{~cm}$ broad, beige (4C3) to olive brown (4D3), thin, papery, dry. Peristome beak-like, up to $2 \mathrm{~mm}$ tall, with grey (2B2) soft silky fibrils extending radially from ostiole to a slight depression. Pseudoparenchy- matous layer orange red (8A8) to brown red (8C8), up to $2 \mathrm{~mm}$ thick, persistent. Outer mycelial layer thin, felted and easily peeled off to reveal underlying fibrous layer of the peridium, slightly encrusted with debris. Gleba white, cottony when young, with radial fibrils, then turning dark brown (6F8) and powdery before outer the peridium begins to split open, pseudocolumella distinct.

Basidiospores dark brown (6F8) in mass, epispore light brown (6D8) to brown (6E8) in $5 \% \mathrm{KOH}$, slightly thick to distinctly thickened (Fig. 6d), appearing smooth under light microscope (LM) (Figs. 6a-e) but subsmooth, punctate, minutely and irregularly verruculose under scanning electron micro- 


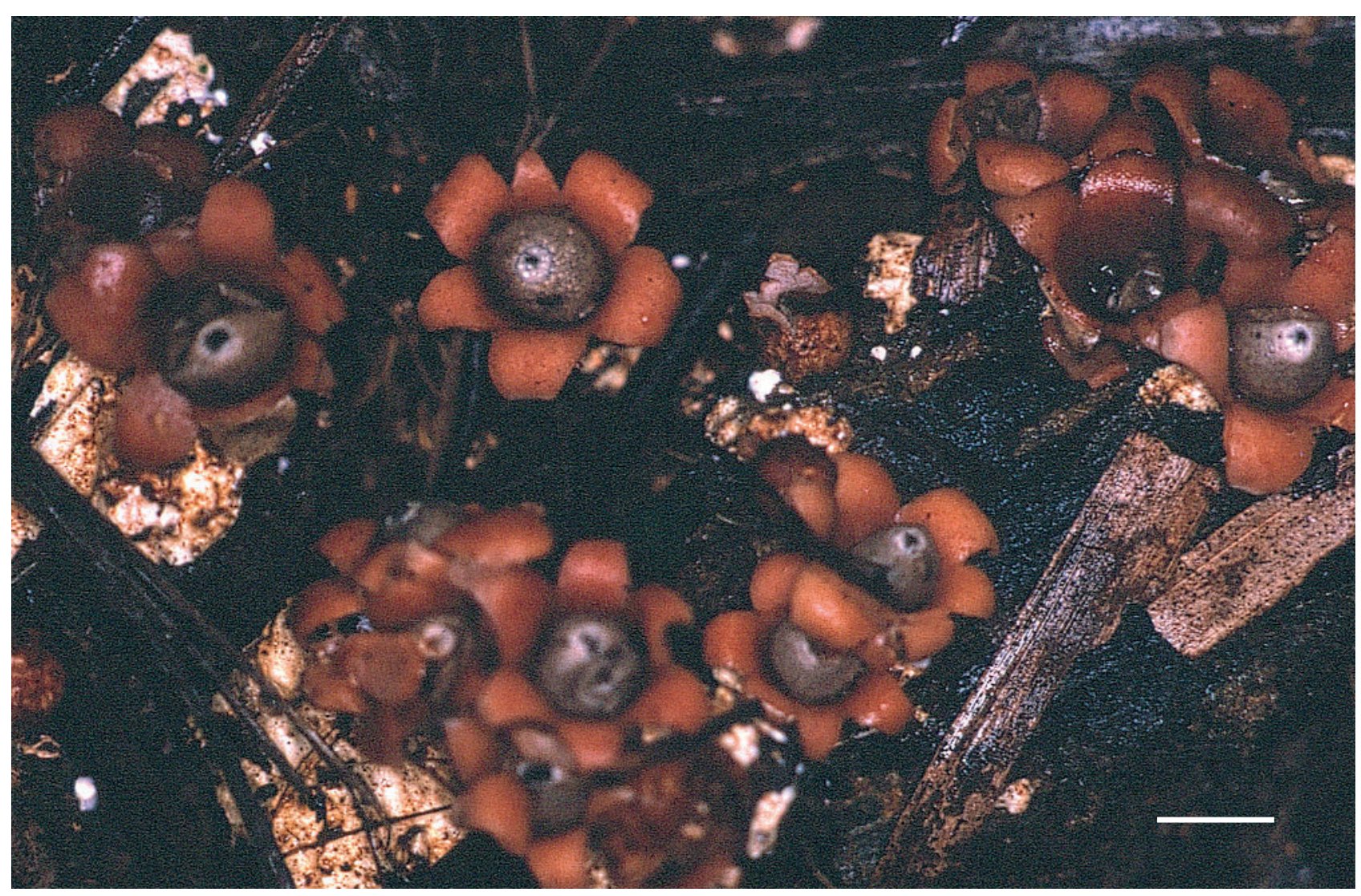

Fig. 4: G. pleosporus (Holotype DMC 224): mature fruitbodies. Scale bar $=1 \mathrm{~cm}$.

Photo: C. Douanla-Meli.

scope (SEM) (Figs. 7a-d), very variable in size and shape, (3.5) 4-6 (8) × (3) 4-5 (6) $\mu \mathrm{m}$, globose, cylindrical, elliptic, reniform, club-shaped, producing constricted spores (Figs. 5b, $6 \mathrm{~b}, 6 \mathrm{~d})$, sometimes showing a mid-length to subapical constriction, that narrowing gradually and may be developed to a deep strangulation, thus the eight-shaped.

Basidia only observed in young gleba, $15.5-19 \times 4-5.5 \mu \mathrm{m}$, clavate, ventricose to flask-shaped with a more or less long collar, (2) 4-8 spored, long pedunculate with basal clamp, continuing with hyaline fibrils (Fig. 5a). Capillitium threads (Figs. 5c and 6e) abundant, almost tinted, yellowish brown (5E8) to dark brown (6F8), 1.5-4.5 $\mu \mathrm{m}$ broad, thick-walled, lumen narrowing, much reduced, or even absent, fusiform to cylindrical, continuous, strongly attenuating towards the ends, unbranched or seldom with acute branches at apices, attached to the pseudo-columella and the inner wall of the endoperidium. Endoperidium of tightly interwoven hyphae, 2.5-6 $\mu \mathrm{m}$ broad, hyaline to pale yellow (3A3), thick-walled with large or narrow lumen, at times dichotomously branched, tapering towards the ends. Fleshy layer consisting of pale yellow (3A3) to yellow (2B8), thin- to slightly thick-walled cells, up to $35 \mu \mathrm{m}$ broad. Exoperidium composed of tight hyphae (Fig. 5d), hyaline to light brown (5D7), 10-16 $\mu \mathrm{m}$ broad, thick-walled, walls up to $7 \mu \mathrm{m}$ thick, with narrow lumen, stout, attenuating towards the base, intermixed with hyaline, interwoven hyphae up to $13 \mu \mathrm{m}$ broad.
Habitat and ecology: Scattered to gregarious on decayed wood debris and leaves under Triplochiton scleroxylon K. Schum. (Sterculiaceae), Ayous, in semi-deciduous forest rich in Sterculiaceae and Ulmaceae.

Material studied: CAMEROON, Centre Province, Department of Nyong \& So'o, in the Mbalmayo forest reserve, $47 \mathrm{~km}$ South east of Yaounde, $11^{\circ} 14^{\prime}-11^{\circ} 54^{\prime} \mathrm{E}$ and $3^{\circ} 5^{\prime}-3^{\circ} 58^{\prime} \mathrm{N}, 500-650 \mathrm{~m}$ asl., 16.X.2002, leg. C. Douanla-Meli. Holotype DMC 224 (HUYI), Isotype 56971 (MA- Fungi).

\section{Discussion}

Few studies are carried out on the species of Geastrum from the tropics. In 1962 DISSING \& LANGE published a work on the Gasteromycetes of Congo, where they distinguished 20 species. Later, DRING (1964) described 8 species from West Tropical Africa, Demoulin \& Dring (1975) reported 8 species from Eastern Central Africa. Regarding the neotropics, CALONGE, MorenO-Arroyo \& GÓMEZ (2000) have described a new species, G. ovalisporum from Bolivia, and recently BASEIA \& MILANEZ (2002) proposed G. setiferum as a new species from Brazil. In the absence of a comprehensive monograph of $\mathrm{Ge}$ astrum, the most complete work on the world species of the genus Geastrum is that of PONCE DE LEÓN (1968), and elsewhere the study of Northern European species by SUNHEDE (1989). The morphological characteristics and the sequence data 


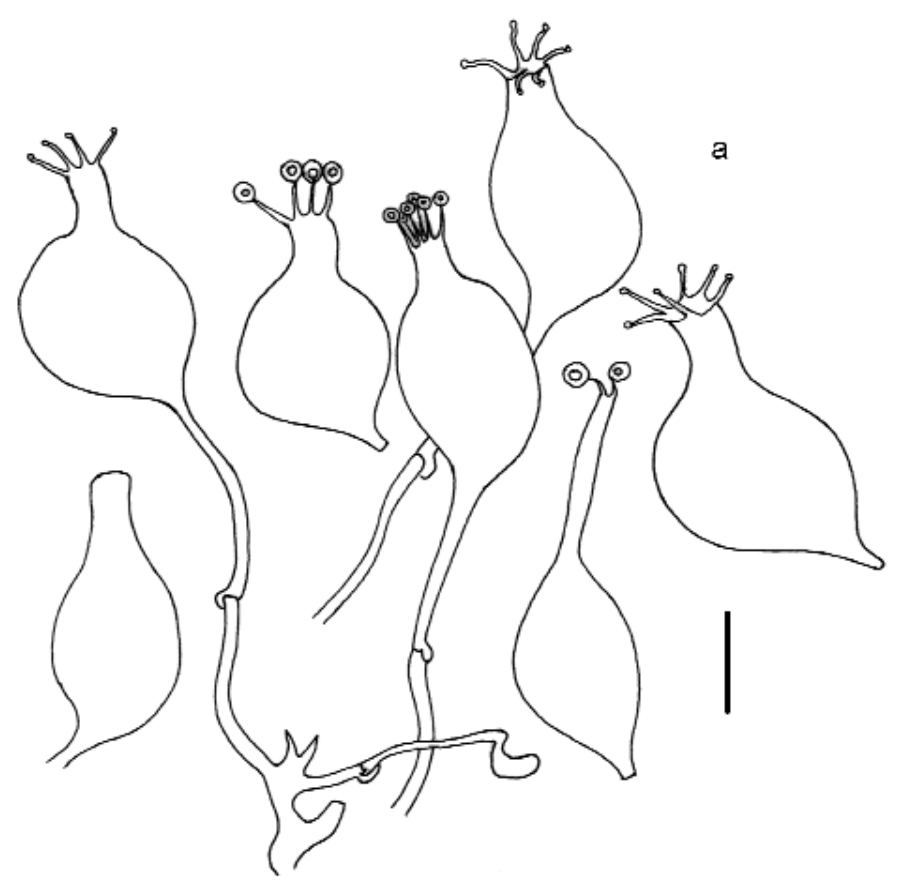

b
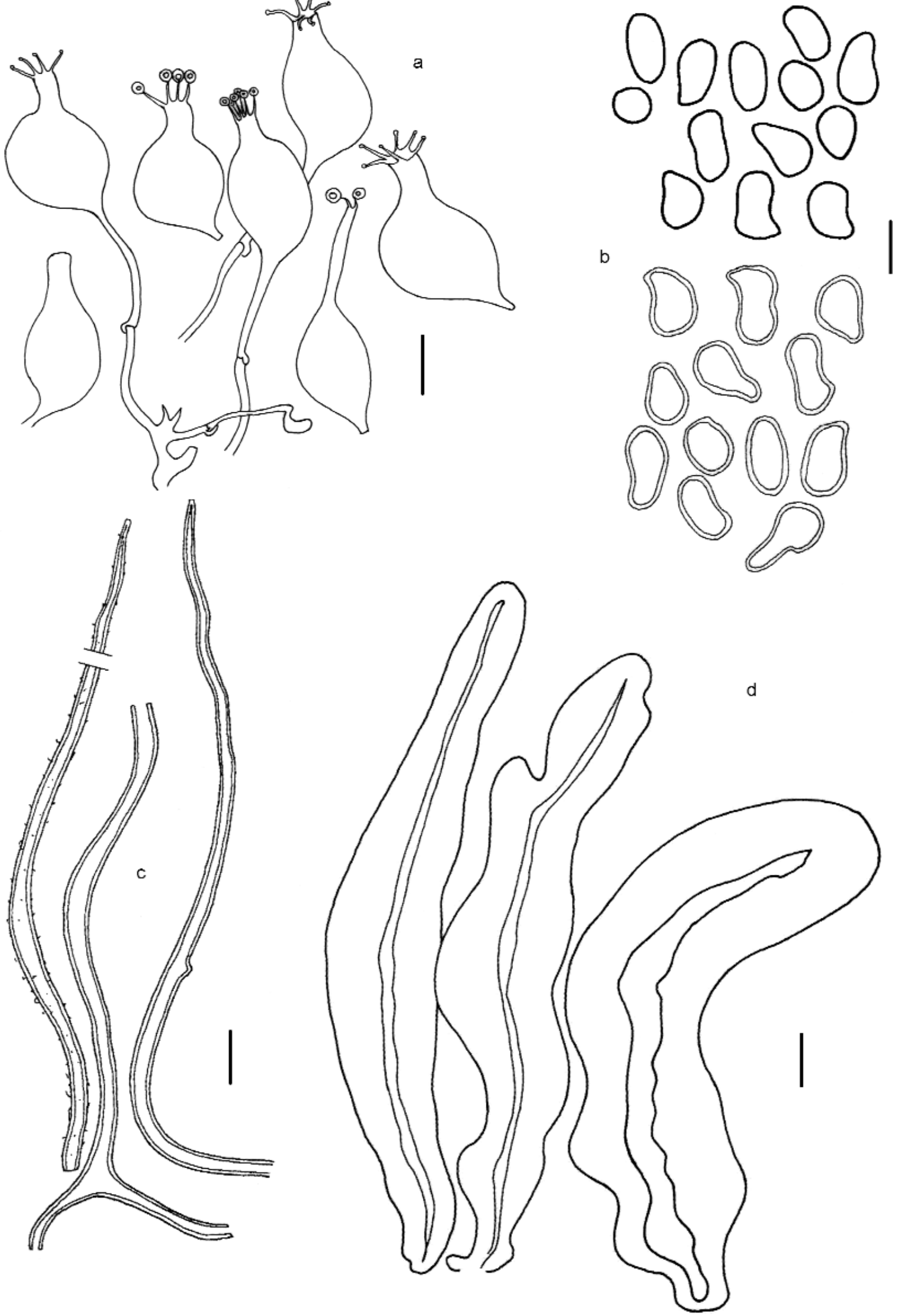

Fig. 5: G. pleosporus (Holotype DMC 224). - a. basidia ventricose, long pedunculate, with basal clamped, continuing with hyaline fibrils, only observed in young gleba. - b. basidiospores as seen by LM, smooth, very variable in shape and size, with slightly thick-to thickened walls. - c. thick-walled capillitium threads, strongly tapering with acute ends, may be finely incrusted with debris. $-\mathbf{d}$. thick-walled hyphae of the exoperidium, cylindrical, with narrow lumen. Scale bars $=5 \mu \mathrm{m}$. 

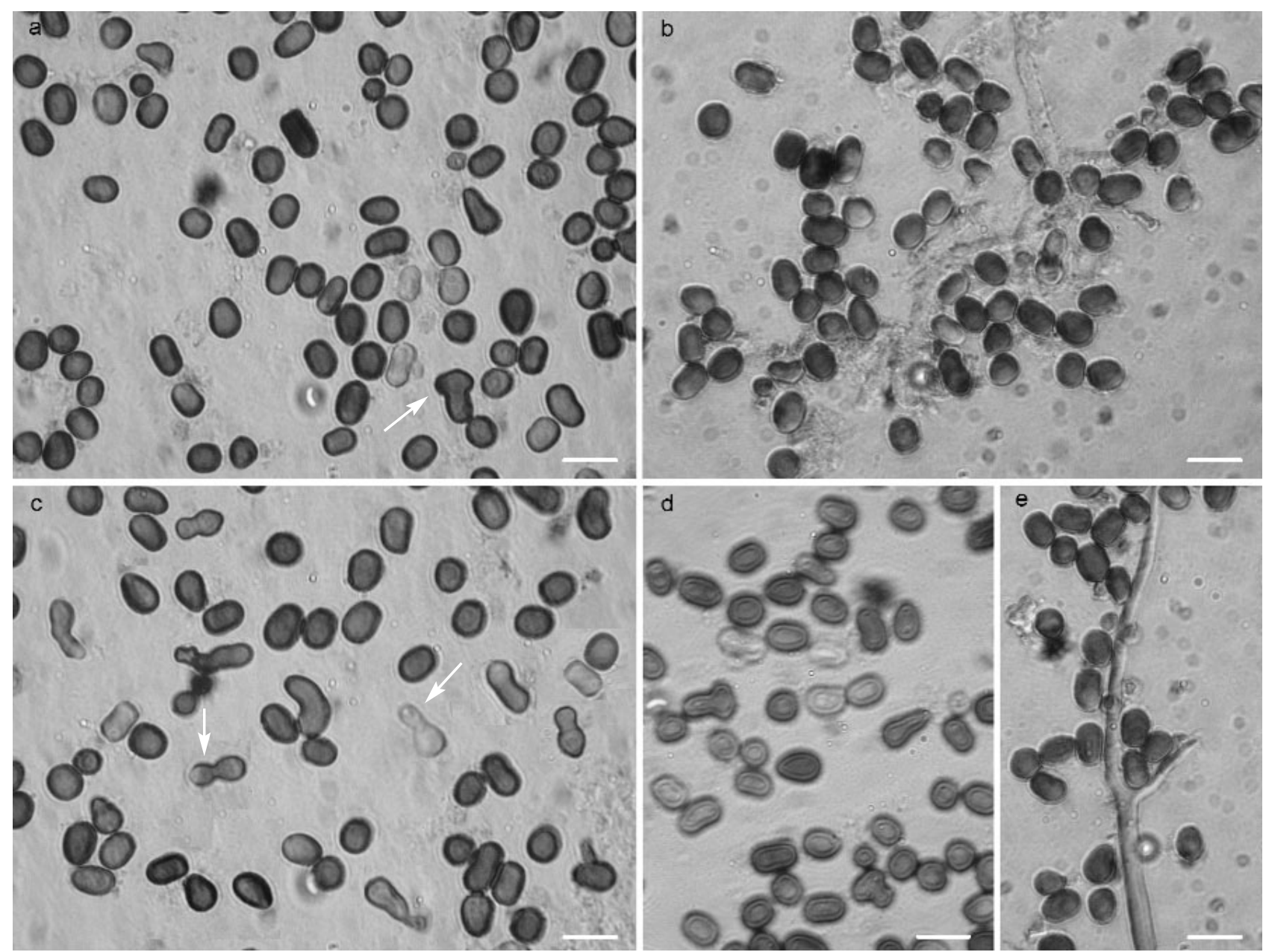

Fig. 6: G. pleosporus (Holotype DMC 224): Micrographs from LM. - a-c. basidiospores smooth, with variable forms, globose, elliptic, club-shaped to eight-shaped showing a mid-length to subapical constriction (arrows). - d. basidiospores showing thickened walls. - e. capillitium threads with acute, subapical branches. Scale bars $=5 \mu \mathrm{m}$.

of LSU rDNA demonstrated that our collection from Cameroon represented a new species of Geastrum in tropical Africa.

Morphologically, G. pleosporus is characterised by having minute basidiomata, orange red to brown red, thick-walled capillitium occasionally with apical acute branches, pleomorphous, and smooth to subsmooth spores. The characteristic simple or freely branched capillitium threads in G. pleosporus remind of species of Lycoperdaceae (KRÜGER et al. 2001), but based on the number of layers of the fruitbody, more than two, the new species is assigned to the Geastrales that includes the genera Geastrum, Myriostoma and Ragdiigera. It further shows a spore sac with a unique stoma distinguishing the genus Geastrum. G. pleosporus belongs to a group that is characterised by having a subiculose mycelium, with only four taxa (Ponce De LeÓn 1968). Two of them, G. javanicum Lév. and G. javanicum var. welwitschii can be separated by an exoperidium whose external layer splits into two fibrous persistent layers; while the other two, G. schweinitzii and its variety G. schweinitzii var. stipitatum (Solms ex Fischer) P. Ponce, differ from $G$. pleosporus by having bigger basidioma $(2-5 \mathrm{~cm}$ broad) and always globose and smaller (3.2-3.8 $\mu \mathrm{m}$ diameter) spores. G. subiculosum (Cooke \& Massee) G. H. Cunningham also grows crowded upon a white subiculum covering the surface of decaying vegetable debris; it is however easily identified by the globose and small, almost smooth to delicately verruculose spores. Another species morphologically similar to G. pleosporus is G. velutinum. It has a sessile endoperidium, non-hygroscopic exoperidium similar to G. pleosporus. Both species also have a shallow depression at the base of the peristome. However, the peristome of G. velutinum is pubescent, non sulcate, surrounded by a dark ring. It also differs in the well-developed, dark brown, velutinous ornamentation covering the external surface. Concluding from the characters of the endoperidium and the slightly depressed disc surrounding the apical pore, G. pleosporus could also be related to G. sessile and G. saccatum, but it is easily distinguished by its colour. It becomes obvious that the species placed in the genus Geastrum resemble one another so closely that separation is frequently a difficult matter, and the taxonomic value of morphological features is not any more efficient to warrant the erection of new taxa. Nevertheless, the best features to separate $G$. pleosporus from other known species is 

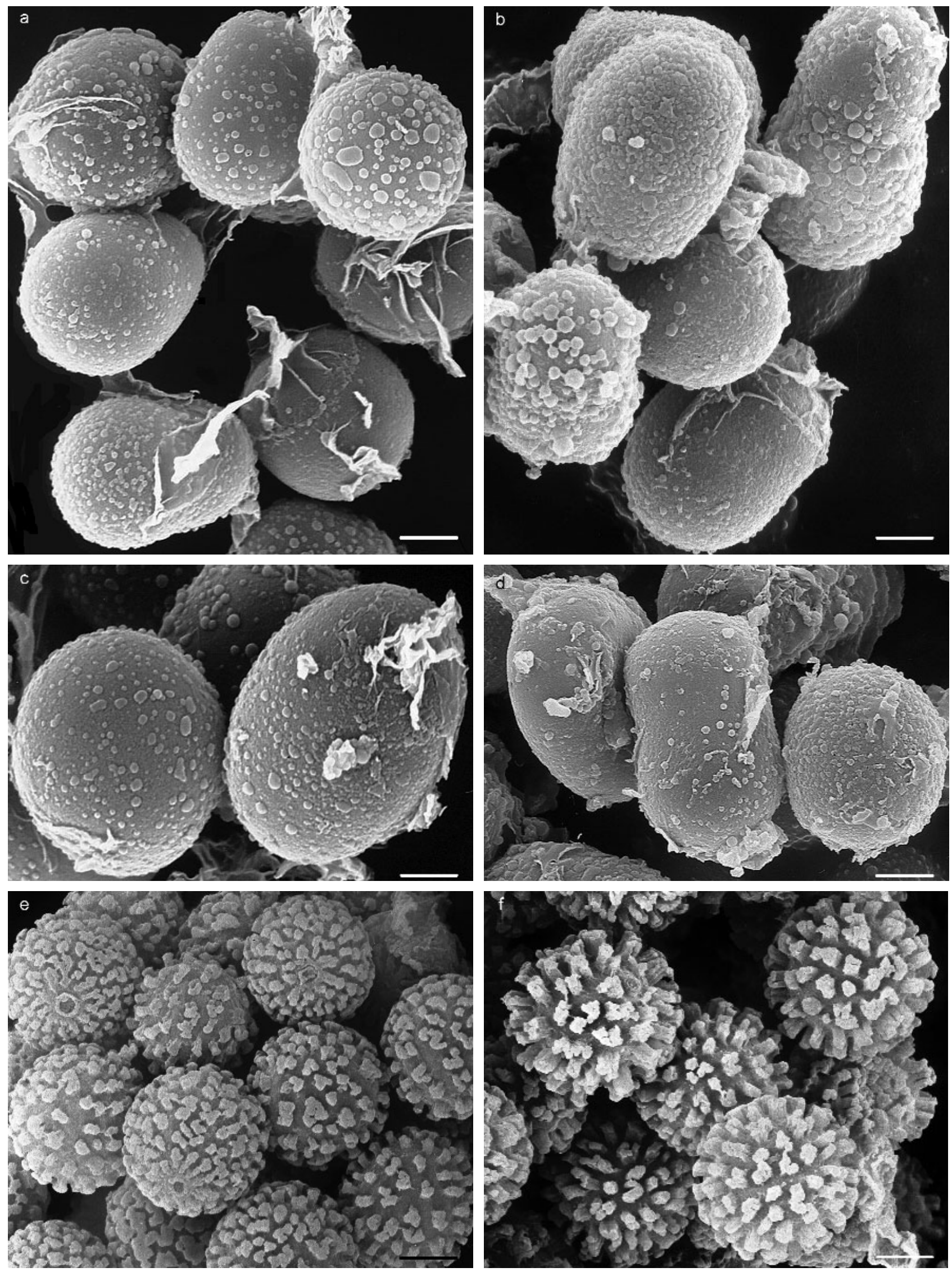

Fig. 7: SEM micrographs of basidiospores. - a-d. G. pleosporus (Holotype DMC 224); basidiospores subsmooth to minutely and irregularly verruculose, variable in shape. - e. G. saccatum (DMC 227); basidiospores globose, densely warted. - f. G. fimbriatum (DMC 290); basidiospores globose, with coarsely, densely arranged column-shape warts. Scale bars $=1 \mu \mathrm{m}$. 
based on spores. They are less subject to variation than other features of this variable genus, and their size and markings afford useful specific characters (CUNNINGHAM 1979, DRING 1964). G. pleosporus does not display the globose to subglobose, warted spores common in the genus Geastrum, but shows spores with uncommon patterns in shape, mostly ellipsoid, reniform, ovoid, elongate to constricted, thick-walled and widely ranging in size. Such unusual spores have not been found in other described species of Geastrum. They were observed from all individual basidiomata of the collection. $G$. pleosporus shows a combination of characters, such as tiny orange-red basidiomata, presence of a subiculose mycelium and polymorphic subsmooth to verruculose spores, which confer this taxon a unique identity.

We employed rDNA sequence analysis to clarify the generic placement of G. pleosporus. Analysis of LSU rDNA placed G. pleosporus in the Gasteromycetes in a clade among other Geastrum species. Analysis of two datasets with representatives of different Gasteromycetes groups and Geastrum species together with related taxa clearly associated G. pleosporum with G. saccatum, as initially indicated by the results of BLAST search using the two LSU rDNA sequences generated from $G$. pleosporus. In both parsimony and maximum likelihood analyses, G. pleosporus and G. saccatum formed a cluster with high bootstrap support. Results of the parsimony analysis based on LSU rDNA warrant its placement in the genus Geastrum. G. sessile and G. fimbriatum however are distantly related to this cluster. The sessile spore sac does not appear to be a reliable indicator of relatedness among Geastrum species. Two of the Geastrum species within the clade have slightly raised spore sacs, and are more related to G. pleosporus than G. sessile and G. fimbriatum. Indeed, G. pleosporus has morphological similarities with $G$. saccatum and other species of the genus. Phylogenetic analysis showed relationships and differences with the former species. On the other hand it is recognised as a distinct species based on spores patterns and smaller size of the fruitbodies.

\section{Acknowledgements}

The authors appreciate the help of Mr. Harald Rühling of Cellular Biology Department with SEM photography and Dr. Alexandra Riethmüller for a technical management in the laboratory. Furthermore, Mr. Zambo Robert is thanked for facilitating fieldwork. The comments of three anonymous reviewers were very helpful for improving the manuscript. This research was financially supported by the grant A/01/20502 from the German Academic Exchange Service (DAAD) to the senior author.

\section{References}

BASEIA IG, MilANEZ AI (2002) Geastrum setiferum (Gasteromycetes): A new species with a setose endoperidium. - Mycotaxon 84: $135-139$.
CALONGe FD (1998) Gasteromycetes. I. Lycoperdales, Nidulariales, Phallales, Sclerodermatales, Tulostomatales. - Flora Mycologica Iberica 3: 1-271.

Calonge FD, Daniëls PP (1998) Fungi of the Dja Biosphere Reserve (Cameroon). Notes on some Gasteromycetes. - Boletín de la Sociedad Micológica de Madrid 23: 135-138.

Calonge FD, Demoulin V (1975) Les Gasteromycètes d'Espagne. - Bulletin de la Société Mycologique de France 91: 247-292.

Calonge FD, Moreno-Arroyo B, Gómez J (2000) Aportación al conocimiento de los Gasteromycetes, Basidiomycotina, de Bolivia (América del Sur). Geastrum ovalisporum sp. nov. Boletín de la Sociedad Micológica de Madrid 25: 271-276.

CunNINGHAm GH (1979) The Gasteromycetes of Australia and New Zealand. - Bibliotheca Mycologica 67: 1-227.

Demoulin V, Dring DM (1975) Gasteromycetes of Kivu (Zaïre), Rwanda and Burundi. - Bulletin Jardin Botanique National de Belgique 45: 339-372.

Dissing H, LANGE M (1962) Gasteromycetes of Congo. - Bulletin Jardin Botanique de 1'Etat, Bruxelles 32: 325- 416.

DRING DM (1964) Gasteromycetes of West Tropical Africa. - Mycological Papers 98: 1-60.

EdWARds K, Johnstone C, THOMPSON C (1991) A simple and rapid method for the preparation of plant genomic DNA for PCR analysis. - Nucleic Acids Research 19: 1349.

FELSENSTEIN J (1985) Confidence limits on phylogenies: an approach using the bootstrap. - Evolution 39: 783-791.

Greuter W, Barrier FR, Burdet H-M, Demoulin V, Filguerias TS, McNeill J, Nicolson DH, Silva PC, Skog JE, TrehaNE P, TuRland NJ, HAwKsworth DL, eds. (2000) International Code of Botanical Nomenclature. (St. Louis Code). Regnum Vegetabile 137. Koeltz Scientific Books, Königstein.

Henrion B, Le TACON F, MARTIN F (1992) Rapid identification of genetic variation of ectomycorrhizal fungi by amplification of ribosomal RNA genes. - New Phytologist 122: 289-298.

Hibbett DS, Pine EM, LANGer E, LANGer G, Donoghue M.J (1997) Evolution of gilled mushrooms and puffballs inferred from ribosomal DNA sequences. - Proceedings of National Academy of Science USA, 94: 12002-12006.

HiLls DM, Bull JJ (1993) An empirical test of bootstrapping as a method for assessing confidence in phylogenetic analysis. Systematic Biology 42: 182-192.

HJortstam R, Ryvarden L, WatLing R (1993) Preliminary checklist of non-Agaricoid Macromycetes in the Korup National Park, Cameroon and surrounding area. - Edinburgh Journal of Botany 50: 105-119.

Holmgren PK, Holmgren NH, Barnett LC (1990) Index Herbariorum. Part I. The Herbaria of the World $8^{\text {th }}$ edition. Regnum Vegetabile vol. 120. New York Botanical Garden.

Humpert AJ, Giachini AJ, Muench EL, Gastellano MA, SpataFORA JW (2001) Molecular phylogenetics of Ramaria and related genera: evidence from nuclear large subunit and mitochondrial small subunit rDNA sequences. - Mycologia 93: 465-477.

KIMURA M (1980) A simple method for estimating evolutionary rates of base substitutions through comparative studies of nucleotide sequences. - Journal Molecular Evolution 16: 111-120.

Kornerup A, Wanscher JH (1978) Taschenlexikon der Farben, 1400 Farbnuancen und 600 Farbnamen. Zürich-Göttingen. $242 \mathrm{pp}$. 
KrÜGer D, Binder M, Fischer M, Kreisel H (2001) The Lycoperdales. A molecular approach to the systematics of some gasteroid mushroom. - Mycologia 93: 947-957.

Mullis KB, FALOONA FA (1987) Specific synthesis of DNA in vitro via a polymerase-catalyzed chain reaction. - Methods Enzymologic 155: 335-350.

O’DonNELL K (1993) Fusarium and its near relatives. In Reynolds DR, Taylor JW (eds) The fungal holomorph: mitotic, meiotic and pleomorph speciation in fungal systematic, pp 225-233. CAB International, Wallingford.

PERSOON CH (1801) Synopsis Methodica Fungorum, 706 p.

Ponce De León P (1968) A revision of the family Geastraceae. Fieldiana Botany 31: 302-349.

PouzAr Z (1971) Geastrum sessile (Sow.) Pouzar, the correct name for Geastrum fimbriatum Fr. (Gasteromycetes). - Folia Geobotanica et Phytotaxonomica Bohemoslovaca. 6: 93-97.

Rambaut A (2002) Sequence Alignment Editor. Version 2.0. Department of Zoology, University of Oxford, South Parks Road, Oxford OXI 4JD, U.K.
Soto MK, Wright JE (2000) Taxonomía del género Geastrum (Basidiomycetes, Lycoperdales) en la provincia de Buenos Aires, Argentina. - Boletín de la Sociedad Argentina de Botánica 34: 185-201.

SunHEDE S (1989) Geastraceae (Basidiomycotina). Morphology, ecology and systematic, with special emphasis on the North European species. Synopsis Fungorum 1. Fungiflora. Oslo.

Swofford DL (2002) PAUP: Phylogenetic Analysis Using Parsimony, version 4.b10. Illinois Natural History Survey: Champion, Illinois.

White TJ, Bruns T, LeE S, TAYLor J (1990) Amplification and direct sequencing of fungal ribosomal RNA genes for phylogenetics. In PCR protocols: a guide to methods and applications. Edited by M.A. Innis, H. Gelfand, J.S. Sninsky, and T.J. White. Academic Press, New York, pp. 315-322.

Accepted: 15.9.2004 